\title{
HYPERHOMOCYSTEINEMIA AND FUNCTIONAL STATE OF ENDOTHELIUM IN PATIENTS WITH PERIPHERAL ARTERY DISEASE WITH ARTERIAL RECONSTRUCTIONS
}

\author{
Kursk State Medical University, Kursk, \\ The Russian Federation
}

Цель. Изучить взаимоотношения гомоцистеина и маркеров функционального состояния эндотелия у пациентов с облитерирующим атеросклерозом при операциях на аорте и артериях нижних конечностей.

Материал и методы. В исследование вошли 68 пациентов с облитерирующим атеросклерозом нижних конечностей, средний возраст $57,8 \pm 7,3$ года, со ІІБ-ІІІ степенью хронической артериальной недостаточности по R. Fontaine-A.B. Покровскому, распределенные на три группы: в I группе выполнено бедренноподколенное шунтирование $(n=32)$, во II - аорто-бедренное шунтирование $(n=20)$, в III - рентгенэдоваскулярная ангиопластика и стентирование подвздошных артерий $(\mathrm{n}=16)$. Проведен корреляционный анализ между содержанием гомоцистеина и маркерами функционального состояния эндотелия: окисленными липопротеинами низкой плотности (окисленными ЛПНП), молекулой адгезии сосудистого эндотелия 1 типа (sVCAM-1), ингибитором тканевого активатора плазминогена 1 типа (PAI-1), тканевым активатором плазминогена (t-PA), Аннексином V в системном и местном кровотоке до операции и после артериальных реконструкций.

Результаты. Установлены корреляционные взаимосвязи между гомоцистеином и окисленными ЛПНП как в системном кровотоке, так и в пораженной конечности, эта ассоциация сохранялась после реконструктивного вмешательства, была наиболее значимой в местном кровотоке после бедренно-подколенного шунтирования. Отмечена дооперационная положительная корреляция системного уровня гомоцистеина и sVCAM-1 в I группе. Показано влияние гомоцистеина на нарушение фибринолитической функции эндотелия, на что указывали прямые корреляционные взаимосвязи между гомоцистеином и PAI-1 в системном кровотоке и в пораженной конечности, сохраняющиеся после открытых реконструкций. Выявлены значимые связи между гомоцистеином и уровнем Аннексина V преимущественно в группе пациентов с поражением бедренно-подколенного артериального сегмента.

Заключение. Гипергомоцистеинемия вносит свой значимый вклад в нарушение функционального состояния эндотелия, оказывая влияние на апоптоз, активацию атерогенных ЛПНП, прокоагулянтный потенциал, сохраняющиеся и после артериальных реконструкций как в системном, так и в местном кровотоке.

Ключевые слова: облитерирующий атеросклероз артерий нижних конечностей, аортоподвздошный сегмент, бедренно-подколенный сегмент, реконструктивные операции, рентгеноэндоваскулярные вмешательства, гомоцистеин, эндотелиальная дисфункция

Objective. To study the relationship between homocysteine and markers of the functional state of the endothelium in patients with obliterating atherosclerosis in operations on the aorta and arteries of the lower limbs.

Methods. The study included 68 patients with peripheral artery disease, the average age was $57.8 \pm 7.3$ years, with II B - III degree of chronic arterial insufficiency according to R. Fontaine-A.V. Pokrovsky, who were divided into three groups: I group underwent the femoropopliteal bypass $(n=32)$, II - the aorto-femoral bypass $(n=20)$, III $-x$-ray endovascular angioplasty and stenting of the iliac arteries $(n=16)$. A correlation analysis was made between the content of homocysteine and the markers of the endothelium functional state of: the oxidized lowdensity lipoproteins (oxidized LDL), a molecule of adhesion of the vascular endothelium type 1 (sVCAM-1), the tissue type 1 plasminogen activator inhibitor (PAI-1), the tissue plasminogen activator (t-PA), Annexin V in the systemic and local bloodstream prior to surgery and after the arterial reconstructions.

Results. Correlation relationships between homocysteine and oxidized LDL were established both in the systemic blood flow and the affected limb, this association persisted after the reconstructive intervention, the most significant in the local bloodstream after femoro-popliteal bypass surgery. Preoperative positive correlation of the systemic level of homocysteine and sVCAM-1 in group I was marked. The effect of homocysteine on the fibrinolytic function of the endothelium was shown, as indicated by the direct correlation between homocysteine and PAI-1 in the systemic blood flow and in the affected limb, which persist after open reconstructions. Significant links between homocysteine and the level of Annexin $\mathrm{V}$ were revealed in the group of patients with the lesion of the femoropopliteal arterial segment.

Conclusions. Hyperhomocysteinemia contributes significantly to the disturbance of the endothelium functional state, affecting apoptosis, the activation of atherogenic LDL, and the procoagulant potential, which persist even after arterial reconstructions both in the systemic and local bloodstream.

Keywords: peripheral artery disease, aortoileal segment, femoropopliteal segment, reconstructive surgeries, $X$-ray endovascular interventions, homocysteine, endothelial dysfunction 
Novosti Khirurgii. 2018 Mar-Apr; Vol 26 (2): 188-194

Hyperhomocysteinemia and Functional State of Endothelium in Patients

with Peripheral Artery Disease with Arterial Reconstructions

V.A. Lazarenko, E.A. Bobrovskaya

\section{Научная новизна статьи}

Изучено взаимоотношение гомоцистеина и маркеров функционального состояния эндотелия у пациентов с облитерирующим атеросклерозом при операциях на аорте и артериях нижних конечностей. Установлено, что у пациентов имеется нарушение функционального состояния эндотелия, выраженность и характер которого коррелируют с уровнем гомоцистеина. Гипергомоцистеинемия вносит значимый вклад в активацию атерогенных ЛПНП, прокоагулянтного потенциала, апоптоза, сохраняющихся после артериальных реконструкций как на системном уровне, так и в пораженной конечности.

\section{What this paper adds}

The relationship between homocysteine and markers of the functional state of the endothelium in patients with obliterating atherosclerosis in operations on the aorta and arteries of the lower limbs has been studied. It has been established that patients have the dysfunctions of the endothelium state, the severity and nature of which correlates with the level of homocysteine. Hyperhomocysteinemia contributes significantly to the activation of atherogenic LDL, procoagulant potential, apoptosis, which persist after arterial reconstructions, both at the systemic level and in the affected limb.

\section{Introduction}

Currently, the endothelial dysfunction is a subject of interest of researchers in the aspect of development of reconstructive angiosurgery complications. There are several forms of endothelial dysfunction: vasomotor, angiogenic, hemostatic, adhesion, in which different biological markers are produced [1].

Indirectly, the functional state of the vascular endothelium can be judged from the content of the damaging factors in the blood, which correlate with the endothelial dysfunction. The homocysteine mechanism of the endothelial cell damage plays a significant role in the development of endothelial dysfunction $[2,3,4]$. It was shown that increased concentrations of homocysteine induce platelet activation, increase thrombogenesis, blood coagulation and decrease fibrinolysis [5].

Previous studies conducted by the authors of this article showed an increased level of homocysteine in patients with obliterating atherosclerosis of the main arteries of the lower limbs, while the local concentration of homocysteine significantly exceeded the systemic level by $48.49 \%$, hyperhomocysteinemia persisted after reconstructive interventions [6].

Objective. To study the relationship between homocysteine and markers of the functional state of the endothelium in patients with obliterating atherosclerosis in operations on the aorta and arteries of the lower limbs.

\section{Methods}

The study included 68 patients with peripheral artery disease, the average age was $57.8 \pm 7.3$ years, with II B - III degree of chronic arterial insufficiency according to R. Fontaine -
A.V. Pokrovsky. The patients were divided into three groups: I group underwent the femoro-popliteal bypass $(n=32)$, II - the aorto-femoral bypass $(n=20)$, III $-x$-ray endovascular angioplasty and stenting of the iliac arteries $(n=16)$. The method of surgical intervention was determined according to the "National guidelines for management of patients with diseases of the lower limb arteries".

The groups were comparable by sex, age (Table 1), the degree of chronic arterial insufficiency. All the patients underwent standard conventional conservative therapy.

Inclusion criteria were male patients with the presence of obliterating atherosclerosis of the aorta and arteries of the lower limbs, chronic arterial insufficiency of the lower limbs of IIB-III degree according to the classification of R. Fontaine-A.V. Pokrovsky.

Exclusion criteria were the presence of autoimmune diseases, inflammatory foci of any localization, diseases of the liver, blood system, acute and chronic diseases in the aggravation stage, diabetes mellitus, cancer at the time of examination or in the anamnesis, decompensated cardiovascular diseases, revascularization of the coronary and peripheral arteries in the anamnesis.

The blood to examine the systemic concentration of markers was taken from the ulnar vein after receiving written informed consent from each patient in the morning on an empty stomach 5 days

Characteristics of patients by age $(\mathrm{M} \pm \sigma)$

\begin{tabular}{cc}
\hline Group of patients & Age \\
\hline I $(n=32)$ & $59.68 \pm 6.48$ \\
II $(n=20)$ & $56.8 \pm 7.68$ \\
III $(n=16)$ & $55.43 \pm 7.89$
\end{tabular}

Note: I-II $-\mathrm{p}<0.05$; I-III $-\mathrm{p}<0.05$; II-III $-\mathrm{p}<0.05$ differences of parameters in the group. The data are presented as $\mathrm{M} \pm \sigma$, where $\mathrm{M}$ - arithmetical mean, - standard deviation of the characteristic. 
before surgery and on the $5^{\text {th }}$ day of the postoperative period. To determine the local concentration of the studied parameters, the content of the latter in the blood plasma taken from the subcutaneous vein of the rear of the foot of the affected limb was determined.

The level of homocysteine in the blood of patients was determined by a solid-phase enzymelinked immunosorbent assay using "eBioscience" reagents (Austria).

As markers of the functional state of the endothelium, the content of the oxidized lipoproteins of low density (oxidized LDL), adhesion molecules of the vascular endothelium type 1 (sVCAM-1), Annexin V, inhibitor of tissue activator of plasminogen type 1 (PAI-1) and tissue plasminogen activator (t-PA) by the method of enzyme immunoassay using reagent kits (Mercodia Oxidized LDD ELISA, "eBioscience", "Technoclone", Austria).

\section{Statistics}

Statistical analysis of the results of the study was carried out using a standard set of office programs. Methods of descriptive statistics, parametric correlation analysis, including the determination of correlation coefficients with R. Fisher's correction, were used. The significance of the characteristics of $\mathrm{p}$ was estimated by calculating the criteria $\mathrm{t}$ and $\mathrm{tz}$ and comparing their values with the control points tst. Differences between groups were considered statistically significant at a significance level of $\mathrm{p}$ $<0.05$.

The mean age values of the patients are presented in the form $\mathrm{M} \pm \sigma$, where $\mathrm{M}$ is the arithmetic mean, $\sigma$ is the standard deviation, the levels of the studied indicators are in the form $\mathrm{M} \pm \mathrm{m}$, where $\mathrm{m}$ is the standard error of the arithmetic mean. The significance of the differences in the average indicators was determined by the Student's $t$ test.

\section{Results}

The level of homocysteine and markers of the functional state of the endothelium is presented in Table 2.

Correlation analysis revealed a significant direct correlation between initial concentrations of homocysteine and oxidized LDL in group I of patients $(\mathrm{r}=0.469, \mathrm{p}<0.01)$ in the systemic blood stream. High postoperative values of homocysteine significantly correlated with the postoperative content of oxidized LDL in group II patients in the operated limb $(r=0.483, p<0.05)$ (Table 3$)$.

A positive correlation was established between the systemic level of homocysteine and SVCAM-1 in the 1st group $(\mathrm{r}=0.426, \mathrm{p}<0.05)$ and a negative correlation of the indices in the group III of patients $(\mathrm{r}=-0.567, \mathrm{p}<0.05)$. After reconstructive interventions, no significant correlations between homocysteine and adhesion molecules were detected

The level of homocysteine and markers of the functional state of the endothelium $(\mathrm{M} \pm \mathrm{m})$

\begin{tabular}{|c|c|c|c|c|c|c|}
\hline \multirow[t]{2}{*}{ Markers } & \multirow{2}{*}{$\begin{array}{l}\text { Group of } \\
\text { patients }\end{array}$} & \multicolumn{2}{|c|}{ Before surgery } & \multicolumn{2}{|c|}{ After surgery } & \multirow{2}{*}{$\begin{array}{c}\text { Reference } \\
\text { parameters }\end{array}$} \\
\hline & & $\begin{array}{c}\text { Systemic blood } \\
\text { flow }\end{array}$ & $\begin{array}{c}\text { Local blood } \\
\text { flow }\end{array}$ & $\begin{array}{l}\text { Systemic blood } \\
\text { flow }\end{array}$ & $\begin{array}{c}\text { Local blood } \\
\text { flow }\end{array}$ & \\
\hline \multirow{3}{*}{$\begin{array}{c}\text { Homocysteine, } \\
\text { mol / L }\end{array}$} & $\mathrm{I}$ & $17.48 \pm 1.62$ & $27.31 \pm 4.47$ & $16.53 \pm 2.49$ & $19.18 \pm 3.09$ & \multirow[t]{3}{*}{$5-12$} \\
\hline & II & $19.95 \pm 3.07$ & $33.46 \pm 6.2$ & $23.2 \pm 6.38$ & $15.56 \pm 0.79^{\#}$ & \\
\hline & III & $26.95 \pm 6.63$ & $32.5 \pm 6.38$ & $26.21 \pm 8.72$ & $37.29 \pm 8.19$ & \\
\hline \multirow[t]{3}{*}{ Oxidized LDL } & $\mathrm{I}$ & $91.56 \pm 1.38$ & $92.56 \pm 2.05$ & $72.71 \pm 1.68^{*}$ & $73.34 \pm 1.7^{\#}$ & \multirow[t]{3}{*}{$26-117$} \\
\hline & II & $96.5 \pm 0.48$ & $100.85 \pm 0.63$ & $79.65 \pm 1.17^{*}$ & $76.4 \pm 1.23^{\#}$ & \\
\hline & III & $104.06 \pm 1.4^{* *}$ & $110.25 \pm 1.36$ & $95.06 \pm 0.98^{*}$ & $85.87 \pm 1.29^{\#}$ & \\
\hline \multirow{3}{*}{$\begin{array}{l}\text { sVCAM-1, } \\
\text { ng/ml }\end{array}$} & $\mathrm{I}$ & $149.19 \pm 17.21$ & $211.72 \pm 18.14$ & $199.57 \pm 13.21^{*}$ & $321.81 \pm 30.43^{\#}$ & \multirow[t]{3}{*}{$131,3-1222,7$} \\
\hline & II & $155.12 \pm 18.68$ & $192.28 \pm 29.13$ & $168.2 \pm 17.49$ & $319.33 \pm 33.35^{\#}$ & \\
\hline & III & $175.79 \pm 26.86$ & $205.54 \pm 31.83$ & $206.26 \pm 28.5$ & $299.83 \pm 33.57^{\#}$ & \\
\hline \multirow{3}{*}{$\begin{array}{c}\text { Annexin } \mathrm{V} \text {, } \\
\mathrm{ng} / \mathrm{ml}\end{array}$} & $\mathrm{I}$ & $0.77 \pm 0.12$ & $0.69 \pm 0.10$ & $1.38 \pm 0.12^{*}$ & $2.72 \pm 0.66^{\#}$ & \multirow[t]{3}{*}{$<0,8$} \\
\hline & II & $2.92 \pm 1.03$ & $1.64 \pm 0.25$ & $2.51 \pm 0.38$ & $2.21 \pm 0.25$ & \\
\hline & III & $0.869 \pm 0.11$ & $0.56 \pm 0.13$ & $1.66 \pm 0.39$ & $1.267 \pm 0.2^{\#}$ & \\
\hline \multirow{3}{*}{$\begin{array}{l}\text { PAI-1, } \\
\text { ng/ml }\end{array}$} & I & $116.03 \pm 4.85$ & $122.94 \pm 5.31$ & $131.96 \pm 6.05^{*}$ & $138.99 \pm 5.76^{\#}$ & \multirow[t]{3}{*}{$4-100$} \\
\hline & II & $134.839 \pm 8.71$ & $126.559 \pm 6.82$ & $121.67 \pm 4.45$ & $101.657 \pm 6.96^{\#}$ & \\
\hline & III & $122.66 \pm 5.95$ & $135.51 \pm 6.53$ & $140.22 \pm 6.37^{*}$ & $196.08 \pm 11.22^{\#}$ & \\
\hline \multirow{3}{*}{$\begin{array}{l}\mathrm{t}-\mathrm{PA}, \\
\mathrm{ng} / \mathrm{ml}\end{array}$} & I & $3.58 \pm 0.19$ & $3.43 \pm 0.32$ & $4.82 \pm 0.39^{*}$ & $4.91 \pm 0.36^{\#}$ & \multirow[t]{3}{*}{$2-8$} \\
\hline & II & $4.15 \pm 0.53$ & $4.57 \pm 0.78$ & $3.31 \pm 0.448$ & $2.659 \pm 0.22^{\#}$ & \\
\hline & III & $4.38 \pm 0.49$ & $3.66 \pm 0.22$ & $5.08 \pm 0.739$ & $4.548 \pm 0.47$ & \\
\hline
\end{tabular}

Note: ${ }^{1}-$ the range of reference values is given according to the instructions to the reagent sets. $*-p<0.05$ relative to systemic concentration before surgery; \# $-\mathrm{p}<0.05$ relative to local concentration before surgery. 
Positive and negative correlation relationships between homocysteine and markers of the functional state of the endothelium

\begin{tabular}{|c|c|c|c|c|c|c|}
\hline & Markers HC & $\begin{array}{l}\text { oxidized LDL } \\
\text { Before surgery }\end{array}$ & sVCAM-1 & PAI-1 & $\mathrm{t}-\mathrm{PA}$ & Annexin V \\
\hline Systemic blood flow & Femoro-popliteal bypass & $\mathrm{r}=0.469^{* * *}$ & $\mathrm{r}=0.426^{* *}$ & $\mathrm{r}=0.682^{*}$ & $\mathrm{r}=-0.236$ & $\mathrm{r}=-0.423^{* *}$ \\
\hline & aorta femoral bypass & $\mathrm{r}=0.101$ & $\mathrm{r}=0.259$ & $\mathrm{r}=-0.23$ & $\mathrm{r}=-0.15$ & $\mathrm{r}=0.039$ \\
\hline & Stents & $\mathrm{r}=-0.145$ & $\mathrm{r}=-0.567^{* *}$ & $\mathrm{r}=0.102$ & $\mathrm{r}=0.215$ & $\mathrm{r}=-0.025$ \\
\hline \multirow[t]{4}{*}{ Local blood flow } & Femoro-popliteal bypass & $\mathrm{r}=0.111$ & $\mathrm{r}=0.267$ & $\mathrm{r}=0.498^{* * *}$ & $\mathrm{r}=-0.167$ & $\mathrm{r}=-0.62^{*}$ \\
\hline & aorta femoral bypass & $\mathrm{r}=-0.06$ & $\mathrm{r}=-0.21$ & $\mathrm{r}=0.248$ & $\mathrm{r}=0.44^{* *}$ & $\mathrm{r}=0.68^{*}$ \\
\hline & Stents & $\mathrm{r}=0.284$ & $\mathrm{r}=0.05$ & $\mathrm{r}=0.604^{* *}$ & $\mathrm{r}=0.236$ & $\mathrm{r}=-0.23$ \\
\hline & & After surgery & & & & \\
\hline \multirow[t]{3}{*}{ Systemic blood flow } & Femoro-popliteal bypass & $\mathrm{r}=0.242$ & $r=0.043$ & $r=0.693^{*}$ & $\mathrm{r}=0.217$ & $\mathrm{r}=-0.479^{* * *}$ \\
\hline & aorta femoral bypass & $\mathrm{r}=0.43$ & $\mathrm{r}=-0.15$ & $r=0.194$ & $r=-0.269$ & $r=-0.09$ \\
\hline & Stents & $\mathrm{r}=0.06$ & $\mathrm{r}=0.039$ & $\mathrm{r}=0.15$ & $\mathrm{r}=-0.205$ & $\mathrm{r}=-0.17$ \\
\hline \multirow[t]{3}{*}{ Local blood flow } & Femoro-popliteal bypass & $r=-0.182$ & $\mathrm{r}=0.279$ & $\mathrm{r}=0.276$ & $\mathrm{r}=0.09$ & $\mathrm{r}=0.661^{*}$ \\
\hline & aorta femoral bypass & $\mathrm{r}=0.483^{* *}$ & $\mathrm{r}=-0.113$ & $r=0.67^{*}$ & $\mathrm{r}=0.07$ & $\mathrm{r}=-0.203$ \\
\hline & Stents & $\mathrm{r}=0.001$ & $r=0.26$ & $\mathrm{r}=-0.147$ & $\mathrm{r}=0.063$ & $\mathrm{r}=-0.23$ \\
\hline
\end{tabular}

in both the systemic blood flow and the operated limb in any of the groups.

Patients with the obliterating atherosclerosis of the aorta and major arteries of the lower limbs were found to have the vascular endothelial dysfunction, characterized by imbalance of fibrinolytic activity with a significant increase in the level of the inhibitor of the tissue activator of type 1 plasminogen. It was this biochemical marker that had a significant correlation with homocysteine. There was a direct correlation between the level of homocysteine and PAI-1 in the group I of patients $(r=0.682, p<0.001)$ in the systemic blood flow, as well as in patients of I and III groups in the affected limb $(r=0.498, p<0.01$ and $r=0.604$, $\mathrm{p}<0.05$, respectively).

This correlation relationship was maintained after open arterial reconstructions. Thus, a positive correlation was established between homocysteine and PAI-1 level in patients of the I group in the systemic circulation $(\mathrm{r}=0.693, \mathrm{p}<0.001)$ and in patients of the II group in the operated limb $(\mathrm{r}=0.67$, $\mathrm{p}<0.001$ ).

The existing initial relationship of homocysteine with the high-intensity PAI-1 level in the local blood stream in the group III $(r=0.604, p<0.05)$ is leveled after angioplasty with stenting.

Initially before surgery, the most significant correlations between homocysteine and t-PA were recorded in the group II of patients in the affected limb $(\mathrm{r}=0.44, \mathrm{p}<0.05)$.

In the postoperative period, there was no significant correlation between homocysteine and t-PA in any of the groups studied.

Between the content of homocysteine and Annexin V, significant correlation relationships were found initially in the systemic blood flow in the group I $(\mathrm{r}=-0.426, \mathrm{p}<0.05)$, which persisted after the operation (femoral-popliteal bypass) $(r=-0.479, p<0.01)$, and before the operation in the local blood flow in the groups I and II $(\mathrm{r}=-0.62$, $\mathrm{p}<0.001$ and $\mathrm{r}=0.68, \mathrm{p}<0.001)$. After reconstructive surgery, significant correlation relationships in the operated limb were observed only in patients of the group I $(\mathrm{r}=0.661, \mathrm{p}<0.001)$.

\section{Discussion}

At present, homocysteine has been shown to be involved in the pathogenesis of many diseases [7]. A high level of homocysteine changes the secretory activity of endotheliocytes, being one of the important factors aggravating the function of the vascular endothelium.

The results obtained in this study indicate that patients with the peripheral artery disease had the vascular endothelial dysfunction due to the increased content of homocysteine as an endothelial damaging factor.

According to the literature, only $1 \%$ of homocysteine contained in the blood is in a restore form, and $99 \%$ is oxidized to disulfide with the formation of free radicals, thereby increasing oxidative stress and realizing the damaging effect on the vascular endothelium both due to direct exposure to autooxidation products. and by increasing the peroxidation of low-density lipoproteins and suppressing the synthesis of DNA in the endothelial cells $[8,9,10]$.

During the study, correlation relationships have been established between the content of homocysteine and oxidized LDL in both the systemic blood flow and the affected limb. The data obtained are consistent with studies indicating 
that the process of oxidation of homocysteine contributes to the oxidation of low density lipoproteins, thereby activating the processes of atherogenesis [8].

To determine the adhesion dysfunction of the endothelium, the most informative indicator is the adhesion molecule of the vascular endothelium type 1 , the increase in their concentration occurs when activated by various damaging factors. Correlation analysis revealed correlations between the initial systemic level of homocysteine and sVCAM-1 in the I and III groups. After performing reconstructive interventions, there was no significant correlation between homocysteine and adhesion molecules in any of the groups, either in the systemic blood flow or in the operated limb. Apparently, the damaging effect of homocysteine has only a small contribution to the development of the adhesion form of endothelial dysfunction.

The pathogenesis of thrombosis in hyperhomocysteinemia is not fully understood and, according to the authors, may be multifactorial [11], while hyperhomocysteinemia, promoting activation of the coagulation cascade and increasing hypercoagulable states, is associated with a risk of unfavorable cardiovascular events and the effectiveness of surgical revascularization [12]. The conducted studies confirm the important role of homocysteine in the disturbance of fibrinolytic function of the endothelium and the excessive production of inhibitors of fibrinolysis activation, as indicated by direct correlation between homocysteine and PAI-1 level. The inhibitor of the tissue activator of type 1 plasminogen plays a key regulatory role in fibrinolysis [13]. Attention is drawn to the correlation between the homocysteine and the inhibitor of the tissue activator of type 1 plasminogen in the local blood stream, suggesting that hyperhomocysteinemia leads to the activation of procoagulant potential in the affected limb, representing a risk factor for the development of thrombotic complications in the arterial reconstruction zone. The data obtained are in agreement with the results of researchers who studied the levels of von Willebrand factor, plasminogen inhibitor activator, thrombomodulin, $\mathrm{C}$-reactive protein in patients with the peripheral arterial diseases combined with high homocysteine levels [14].

It is shown that homocysteine reduces the number of cell sites associated with the tissue activator of plasminogen. The decrease in t-PA activity is due to the competing interaction of homocysteine and the tissue plasminogen activator with the same receptors through Annexin II cofactor, leading to the disruption in the conversion of plasminogen to plasmin and a decrease in fibrinolytic activity [10]. The conducted study revealed direct correlation relationships statistically significant between homocysteine and t-PA before surgery only in the group II patients in the affected limb, reflecting a compensatory increase in fibrinolytic activity in response to the damaging effect of homocysteine.

There is evidence in the literature that a high level of homocysteine increases the number of apoptosis and accelerates aging processes in endothelial cells [7, 15]. Correlation analysis revealed statistically significant links between the content of homocysteine and the level of Annexin V, mainly in the group of patients with femoral-popliteal arterial segment lesions, which draws attention to the presence of an initial inverse relationship, both in the affected limb and in the systemic blood stream, and after the operation in the operated limb, the production of Annexin $\mathrm{V}$ was in direct correlation with the level of homocysteine $(r=0.661, p<0.001)$, which indicated a significant damaging effect of homocysteine on the vascular endothelium, accompanied by the increased apoptosis in the conditions of reperfusion.

\section{Conclusions}

Thus, the results of studies have established that patients with the peripheral artery disease have a disruption of the functional state of the endothelium, the severity and nature of which correlates with the level of homocysteine. Hyperhomocysteinemia contributes significantly to the activation of atherogenic LDL, procoagulant potential, apoptosis, which persists after arterial reconstructions, both at the systemic level and in the affected limb.

\section{Funding}

The work was carried out in accordance with the plan of scientific works of Kursk State Medical University.

The authors did not receive financial support from the manufacturers of medicines.

\section{Conflict of interest}

The authors declare that they have no conflict of interest.

\section{ЛИТЕРАТУРА}

1. Петрищев НН, Васина ЛВ, Власов ТД, Гавришева НА, Меншутина МА. Типовые формы дисфункции эндотелия. Клин-Лаб Консилиум. $2007 ;(18): 31-35$.

2. Цыбикова НМ, Цыбиков МН. Роль гипергомо- 
цистеинемии в патологии человека. Дальневосточ Мед Журн. 2007;(4):110-112.

3. Chia S, Wilson R, Ludlam CA, Webb DJ, Flapan AD, Newby DE. Endothelial dysfunction in patients with recent myocardial infarction and hyperhomocysteinaemia: effects of vitamin supplementation. ClinSci (Lond). 2005 Jan;108(1):65-72. doi: 10.1042/ CS20040150.

4. Steed MM, Tyagi SC. Mechanisms of cardiovascular remodeling in hyperhomocysteinemia. Antioxid Redox Signal. 2011 Oct 1;15(7):1927-43. doi: 10.1089/ ars.2010.3721.

5. Loscalzo J. Homocysteine-mediated thrombosis and angiostasis in vascular pathobiology. J Clin Invest. 2009 Nov;119(11):3203-5. doi: 10.1172/JCI40924.

6. Лазаренко ВА, Бобровская ЕА, Сорокин АВ. Гипергомоцистеинемия: периферический атеросклероз и реконструктивная хирургия. Курск науч-практ Вестн «Человек и Его Здоровье». 2014;(4):63-66.

7. Зобова ДА, Козлов СА. Роль гомоцистеина в патогенезе некоторых заболеваний. Изв Высших Уиеб Заведений. Поволж Регион. Мед науки. 2016;3(39):13244. doi: $10.21685 / 2072-3032-2016-3-15$.

8. Loscalzo J. The oxidant stress of hyperhomocyst(e) inemia. J Clin Invest. 1996 Jul 1;98(1):5-7. doi: 10.1172/JCI118776.

9. IngenbleekY. The oxidative stress of hyperhomocysteinemia results from reduced bioavailability of sulfurcontaining reductants. Open Clin Chem J. 2011;4(1):3444. doi: $10.2174 / 1874241601104010034$.

10. Каражанова ЛК, Жунуспекова АС. Гипергомоцистеинемия как фактор риска сердечно-сосудистых заболеваний (обзор литературы). Наука и Здравоохранение. 2016;(4):129-44. orcid.org/00000003-1496-3281

11. Leoncini G, Bruzzese D, Signorello MG. Activation of p38 MAPKinase/cPLA2 pathway in homocysteine-treated platelets. J Thromb Haemost. 2006;4(1):20916. doi: 10.1111/j.1538-7836.2005.01708.x.

12. Yeh JK, Chen CC, Hsieh MJ, Tsai ML, Yang $\mathrm{CH}$, Chen DY, Chang SH, Wang CY, Lee CH, Hsieh IC. Impact of homocysteine level on long-term cardiovascular outcomes in patients after coronary artery stenting. J Atheroscler Thromb. 2017 Jul 1;24(7):696705. doi: $10.5551 /$ jat.36434.

13. Tofler GH, Massaro J, O'Donnell CJ, Wilson PWF, Vasan RS, Sutherland PA, Meigs JB, Levy D, D'Agostino RB Sr. Plasminogen activator inhibitor and the risk of cardiovascular disease: The framingham heart study. Thromb Res. 2016 Apr;140:30-35. doi: 10.1016/j. thromres.2016.02.002.

14. de Jong SC, Stehouwer CD, van-den Berg M, Vischer UM, Rauwerda JA, Emeis JJ. Endothelial marker proteins in hyperhomocysteinemia. ThrombHaemost. 1997 Nov;78(5):1332-37.

15. Sipkens JA, Hahn N, van den Brand CS, Meischl C, Cillessen SA, Smith DE, Juffermans LJ, Musters RJ, Roos D, Jakobs C, Blom HJ, Smulders YM, Krijnen PA, Stehouwer CD, Rauwerda JA, van Hinsbergh VW, Niessen HW. Homocysteine-induced apoptosis in endothelial cells coincides with nuclear NOX2 and peri-nuclear NOX4 activity. Cell Biochem Biophys. 2013 Nov;67(2):341-52. doi: 10.1007/s12013-011-9297-y.

\section{REFERENCES}

1. Petrishchev NN, Vasina LV, Vlasov TD, Gavri- sheva NA, Menshutina MA. Tipovye formy disfunktsii endoteliia. Klin-Lab Konsilium. 2007;(18):31-35. (in Russ.)

2.Tsybikova NM, Tsybikov MN. Rol' gipergomotsisteinemii v patologii cheloveka. Dal'nevostoch Med Zhurn. 2007;(4):110-112. (in Russ.)

3. Chia S, Wilson R, Ludlam CA, Webb DJ, Flapan AD, Newby DE. Endothelial dysfunction in patients with recent myocardial infarction and hyperhomocysteinaemia: effects of vitamin supplementation. ClinSci (Lond). 2005 Jan;108(1):65-72. doi: 10.1042/ CS20040150.

4. Steed MM, Tyagi SC. Mechanisms of cardiovascular remodeling in hyperhomocysteinemia. Antioxid Redox Signal. 2011 Oct 1;15(7):1927-43. doi: 10.1089/ ars.2010.3721.

5. Loscalzo J. Homocysteine-mediated thrombosis and angiostasis in vascular pathobiology. J Clin Invest. 2009 Nov;119(11):3203-5. doi: 10.1172/JCI40924.

6. Lazarenko VA, Bobrovskaya EA, Sorokin A.V. Hyperhomocysteinemia: peripheral atherosclerosis and reconstructive surgery. Kursk Nauch-Prakt Vestn "Chelovek $i$ Ego Zdorov'e». 2014;(4):63-66. (in Russ.)

7. Zobova DA, Kozlov SA. Rol' gomotsisteina v patogeneze nekotorykh zabolevanii. Izv Vysshikh Ucheb Zavedenii. Povolzh Region. Med Nauki. 2016;3(39):13244. doi: 10.21685/2072-3032-2016-3-15. (in Russ.)

8. Loscalzo J. The oxidant stress of hyperhomocyst(e) inemia. J Clin Invest. 1996 Jul 1;98(1):5-7. doi: 10.1172/JCI118776.

9. IngenbleekY. The Oxidative stress of hyperhomocysteinemia results from reduced bioavailability of sulfurcontaining reductants. Open Clin Chem J. 2011;4(1):3444. doi: 10.2174/1874241601104010034.

10. Karazhanova LK, Zhunuspekova AS. Hyperhomocysteinemia as a risk factor of cardiovascular diseases (literature review). Nauka $i$ Zdravookhranenie. 2016;(4):129-44. orcid.org/0000-0003-1496-3281. (in Russ.)

11. Leoncini G, Bruzzese D, Signorello MG. Activation of p38 MAPKinase/cPLA2 pathway in homocysteine-treated platelets. J Thromb Haemost. 2006;4(1):20916. doi: 10.1111/j.1538-7836.2005.01708.x.

12. Yeh JK, Chen CC, Hsieh MJ, Tsai ML, Yang $\mathrm{CH}$, Chen DY, Chang SH, Wang CY, Lee CH, Hsieh IC. Impact of homocysteine level on long-term cardiovascular outcomes in patients after coronary artery stenting. J Atheroscler Thromb. 2017 Jul 1;24(7):696705. doi: $10.5551 /$ jat.36434.

13. Tofler GH, Massaro J, O'Donnell CJ, Wilson PWF, Vasan RS, Sutherland PA, Meigs JB, Levy D, D'Agostino RB Sr. Plasminogen activator inhibitor and the risk of cardiovascular disease: The framingham heart study. Thromb Res. 2016 Apr;140:30-35. doi: 10.1016/j. thromres.2016.02.002.

14. de Jong SC, Stehouwer CD, van-den Berg M, Vischer UM, Rauwerda JA, Emeis JJ. Endothelial marker proteins in hyperhomocysteinemia. ThrombHaemost. 1997 Nov;78(5):1332-37.

15. Sipkens JA, Hahn N, van den Brand CS, Meischl C, Cillessen SA, Smith DE, Juffermans LJ, Musters RJ, Roos D, Jakobs C, Blom HJ, Smulders YM, Krijnen PA, Stehouwer CD, Rauwerda JA, van Hinsbergh VW, Niessen HW. Homocysteine-induced apoptosis in endothelial cells coincides with nuclear NOX2 and peri-nuclear NOX4 activity. Cell Biochem Biophys. 2013 Nov;67(2):341-52. doi: 10.1007/s12013-011-9297-y. 
Адрес для корреспонденции

305041, Российская Федерация,

г. Курск, ул. К. Маркса, д. 3,

Курский государственный медицинский университет» Минздрава России, кафедра хирургических болезней факультета последипломного образования, тел.: +7 (4712) 58-81-32,

e-mail: azaroks@mail.ru,

Лазаренко Виктор Анатольевич

\section{Сведения об авторах}

Лазаренко Виктор Анатольевич, д.м.н., профессор, ректор, заведующий кафедрой хирургических болезней факультета последипломного образования, Курский государственный медицинский университет, г. Курск, Российская Федерация.

http://orcid.org/0000-0002-2069-7701

Бобровская Елена Анатольевна, к.м.н., доцент кафедры хирургических болезней факультета последипломного образования, Курский государственный медицинский университет, г. Курск, Российская Федерация.

https://orcid.org/0000-0003-3898-5522

\section{Информация о статье}

Поступила 26 июня 2017 г.

Принята в печать 31 октября 2017 г. Доступна на сайте март 2018 2.
Address for correspondence

305041, The Russian Federation,

Kursk, K.Marx Str., 3,

Kursk State Medical University,

Department of Surgical Diseases

of the Faculty of Post-Graduate Training,

Tel.: +7 (4712) 58-81-32,

e-mail: azaroks@mail.ru,

Lazarenko Viktor A.

\section{Information about the authors}

Lazarenko Viktor A., MD, Professor, Rector, Head of the Department of Surgical Diseases of the Faculty of Post-Graduate Training, Kursk State Medical University, Kursk, Russian Federation.

http://orcid.org/0000-0002-2069-7701

Bobrovskaya Elena A., PhD, Associate Professor of the Department of Surgical Diseases of the Faculty of PostGraduate Training, Kursk State Medical University, Kursk, Russian Federation.

https://orcid.org/0000-0003-3898-5522

\section{Article history}

Arrived 26 June 2017

Accepted for publication 31 October 2017 Available online March 2018 